\title{
超音波微細気泡を用いた表面洗浄様相の微視的様相観察 Micro-scale observations in surface cleaning using ultrasonic microbubble
}

\author{
○学 太田 慎一郎（金沢工大・院） 正 杉本 康弘（金沢工大） 正 佐藤 恵一（金沢工大） \\ Shinnichiro Ohta, Yasuhiro Sugimoto and Keiichi Sato \\ Kanazawa Institute of Technology, 7-1 Oogigaoka, Nonoichi, Ishikawa
}

Key Words: Micro bubble, Ultrasonic wave, High-speed video observation, Stain removal, Bubble behavior

\section{1. 諸言}

超音波によって駆動される気泡は古くから超音波洗浄に 用いられている。近年，医療に関連した分野において積極 的に利用されてきており ${ }^{(1)}$ ，結石破砕などでは，工夫され た超音波周波数制御によってキャビテーション気泡を生成 後, 生成された気泡の共振周波数に対応した超音波照射に よって激しく微細気泡群を崩壊させている ${ }^{(2)}$. この際付加 する超音波の出力は非常に大きなもので，大規模な試験装 置を要する。産業分野において用いられる超音波洗浄は比 較的低出力であり, 製造工程において効果的に用いられて いる. しかし, 洗浄のある 1 工程で大まかな洗浄を行う過 程で用いられており, さらに後工程でも複数回の洗浄過程 が必要である。より効果的な洗浄を行うためには，気泡挙 動および壁面への衝撃作用のメカニズムを明らかにする必 要がある。

本研究では比較的低出力の超音波を用いた気泡による洗 浄技術の開発を目的としている. その第 1 歩として特に, 超音波によって駆動される気泡挙動と污れ除去様相を詳細 に観察すると同時に，周囲音圧を計測した結果について示 す.

\section{2. 実験装置}

実験装置の概略図を図 1 に示す。超音波発生装置として 電歪型振動子（日本アレックス，NEOSONIC NH300）を使 用した. 出力 $\mathrm{P}$ は $100 \mathrm{~W}$ で振動周波数は $40 \mathrm{kHz}$ である. 高 速度ビデオカメラ(Photron, SA5, 撮影速度 $\mathrm{Fs}=210 \mathrm{~K} \sim$ $420 \mathrm{~K}[\mathrm{fps}])$ に長距離顕微鏡（日本レーザー，ズームレンズ） を用いて撮影を行った。メタルハライドランプ (Photron, HVC-UL）を高速度ビデオカメラと同軸上に配置し，バッ クライトでの撮影を行った。超音波発生装置から水面まで の高さ $\mathrm{H}=130 \mathrm{~mm}$ とし, 超音波発生装置から観察領域まで の高さ $\mathrm{h}=65 \mathrm{~mm}$ とした。また，音圧の計測には 2 種類の八 イドロフォン（B\&K, 8103 and Muller, Platte Needleprobe) を図 1 のように配置し，映像と同時に計測した。ここで試 料水には水道水を用い, 水温 $\mathrm{Tw}=293-295 \mathrm{~K}$, 溶存酸素量 $\beta$ は 7-8mg/L 程度で行った。

\section{3. 実験結果}

図 2 に壁面上に付着した油污れの洗浄様相を示す. 高速 度ビデオカメラによって 40kfps で撮影した. 微細気泡は音 場中で音響流や音響キャビテーション流の効果 ${ }^{(3)}$ などを受 けると考えられ, 振動しながらオイル内に入り，振動し続 ける. その後, オイルの塊から, オイルの微細粒子がはじ き出されるように放出される.

さらに図 3 に壁面上に付着したレジスト膜が除去される 様相観察の結果を示す。ここで試験壁面はシリコンウエハ を用いている. 図中の $\mathrm{t} 0(\mu \mathrm{s})$ は基準となる撮影画像からの 経過時間を示している. $\mathrm{t}_{0}=7.04 \mu \mathrm{s}$ から $\mathrm{t}_{0}=114.14 \mu \mathrm{s}$ のよう
に気泡が壁面近傍で振動している様相が見られる。また， $\mathrm{t}_{0}=114.14 \mu \mathrm{s}$ で気泡が崩壊をした後である $\mathrm{t}_{0}=116.52 \mu \mathrm{s}$ にお いてレジストの塊が浮遊し, $\mathrm{t}_{0}=142.70 \mu \mathrm{s}$ のように移動して いる様相が見られた（図 3(a)矢印 A）。さらに $\mathrm{t}_{0}=237.90 \mu \mathrm{s}$ から $\mathrm{t}_{0}=245.04 \mu \mathrm{s}$ のように気泡が壁面近傍で成長と崩壊を 繰り返しており， $\mathrm{t}_{0}=247.42 \mu \mathrm{s}$ においてはレジストの塊は壁 面近傍に見られなくなった。

図 4 に壁面近傍の気泡挙動を高速度観察した結果および ハイドロフォン出力を示す。ここに試験壁面はシリコンウ エハ上にレジスト膜を付けたものである. 図 4(a)に示され るように, 気泡は壁面近傍で周期的に振動している.図 4(b) に気泡径の変化とハイドロフォンによって計測された音圧 変動の実測值を示す. 気泡の振動周波数は音圧変動とほぼ 対応している。ここに, 気泡の成長より崩壊時のほうが, 急速であることは注目される.

図 5 に気泡崩壊時の様相を示す。気泡は壁面方向へ非球 形的に崩壊する様子が確認できる。このような壁面方向へ の気泡崩壊は壁面壊食を引き起こす高衝撃性の崩壊挙動と して指摘されている(4-5).

高速度ビデオカメラの時間および空間分解能の都合上, 気泡の変形挙動の残像が映りこんでいる. 本撮影時間分解 能 (420kfps) の範囲で気泡は図 5 において $27-30 \mu \mathrm{m}$ 程度変 形していることから，気泡の壁面方向への崩壊速度は少な くとも $10-20 \mathrm{~m} / \mathrm{s}$ 程度であると評価できる。しかしながら， 時間分解能は十分ではないため, さらに高速な崩壊速度現 象の存在が推察される.

\section{4. 結言}

超音波照射下における壁面近傍の微細気泡挙動を高速度 観察した. 気泡の振動周波数はほぼ照射周波数に対応した. この気泡の振動によって固体壁面上の污れが除去される様 相が観察された。気泡が壁面方向への非球形的な高速変形

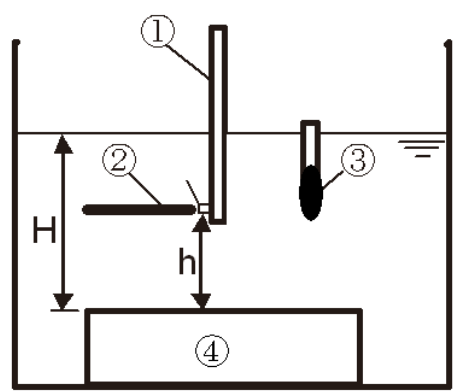

(1) Test specimen (2)Hydrophone A (3)Hydrophone B (4) Ultrasonic vibrator (5) Observation area

Fig.1 Experimental setup 
する挙動を観察した。今後, 気泡変形と発生衝撃の対忘付 けを詳細な計測とともに行う必要がある.

\section{参考文献}

(1) C. E. Brennen, 2003, Cavitation in biological and bioengineering contexts, 5rd Int. Symp. On Cavi., Cav2003, IL-1.

(2) T.Ikeda et al, 2003, Cloud cavitation control for a therapeutic ultrasound application, 5rd Int. Symp. On Cavi., Cav2003, OS-2-1-008.

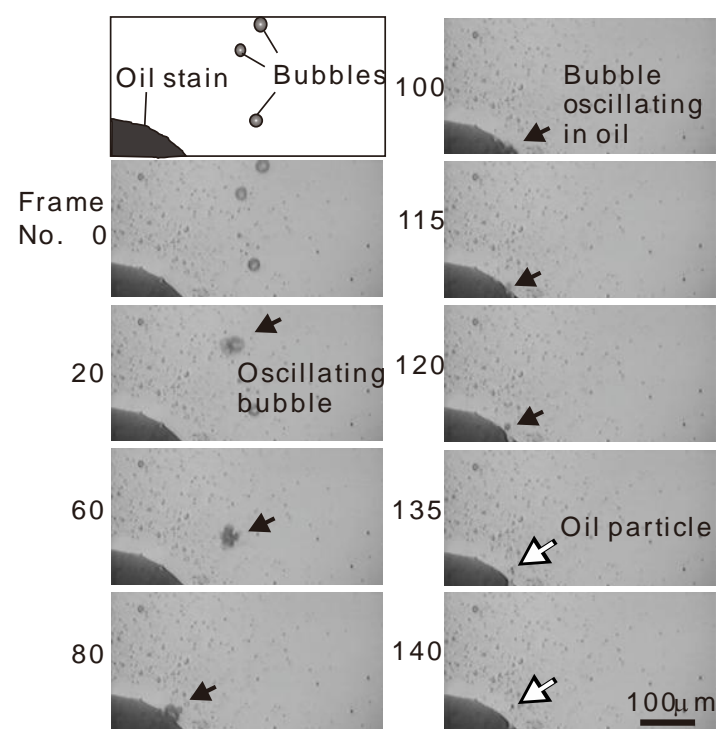

$\mathrm{TW}=292 \mathrm{~K}, \beta=7.0 \mathrm{mg} / \mathrm{L}, \mathrm{Fs}=40 \mathrm{kfps}$, $\mathrm{f}=40 \mathrm{kHz}, \mathrm{P}=100 \mathrm{~W}$

Fig.2 Behavior of bubble and oil stain removal

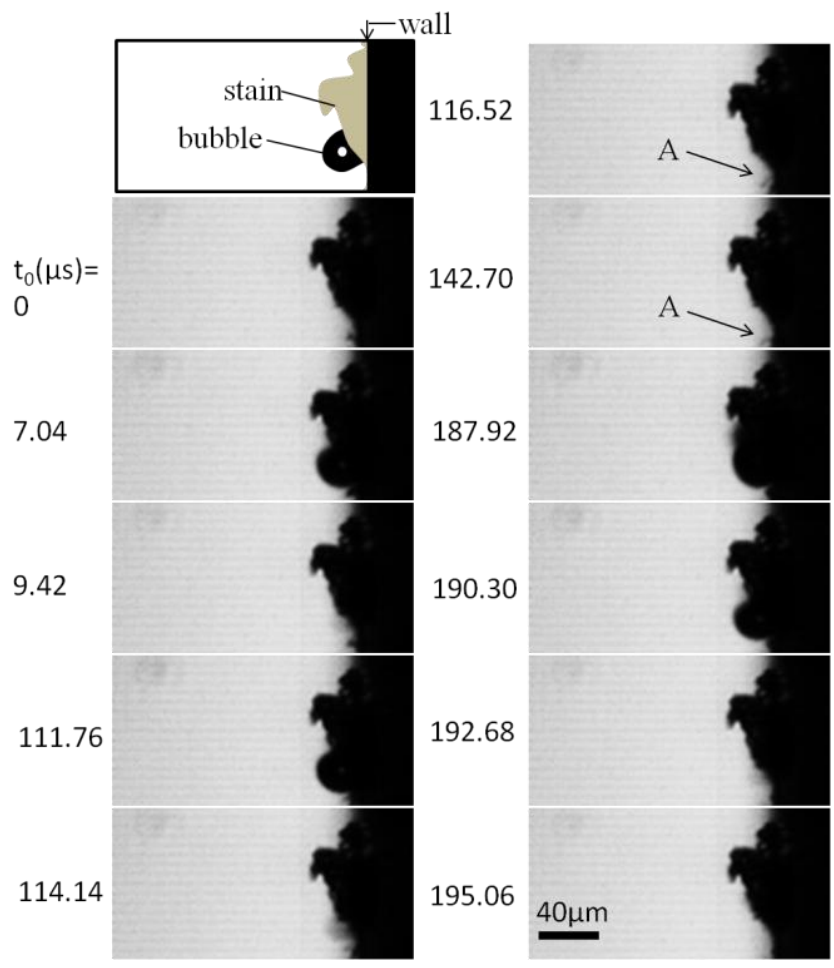

$T w: 293 \mathrm{~K}, \beta: 7.0 \mathrm{mg} / \mathrm{L}, \mathrm{Fs}=420 \mathrm{kfps}, \mathrm{f}=40 \mathrm{kHz}, \mathrm{P}=100 \mathrm{~W}$

Fig.3 Resist removal observation
(3) S. Nomura et al., 2000, Streaming induced by ultrasonic vibration in a water vessel, Jpn. J. Appl. Phys., Vol.39, Part 1, No. 6A, 3636-3640.

(4) Y.Tomita and A.Shima, 1986, Mechanisms of impulsive pressure generation and damage pit formation by bubble collapse, J . Fluid Mech, vol.169, 535-564.

(5) A.Vogel et al., Optical and acoustic investigations of the dynamics of laser-produced cavitation bubbles near a solid boundary, 1989, J . Fluid. Mech,vol.206, 299-338.

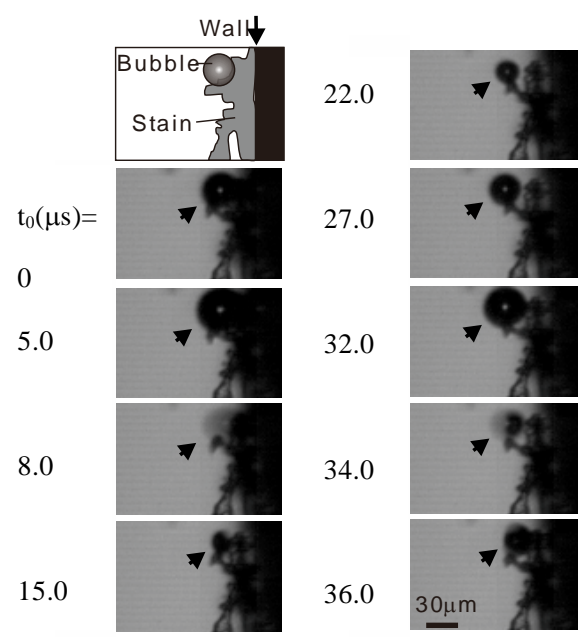

(a) Behavior of bubble

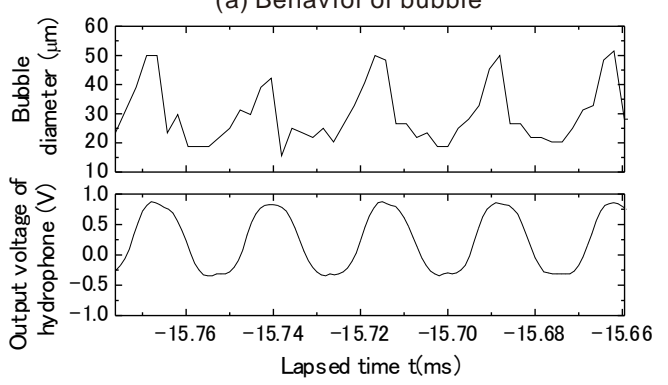

(b)Fluctuation of bubble diameter and sound pressure $\mathrm{Tw}=292 \mathrm{~K}, \beta=7.0 \mathrm{mg} / \mathrm{L}, \mathrm{Fs}=420 \mathrm{kfps}, \mathrm{f}=40 \mathrm{kHz}, \mathrm{P}=100 \mathrm{~W}$

Fig.4 Behavior of bubble and sound pressure

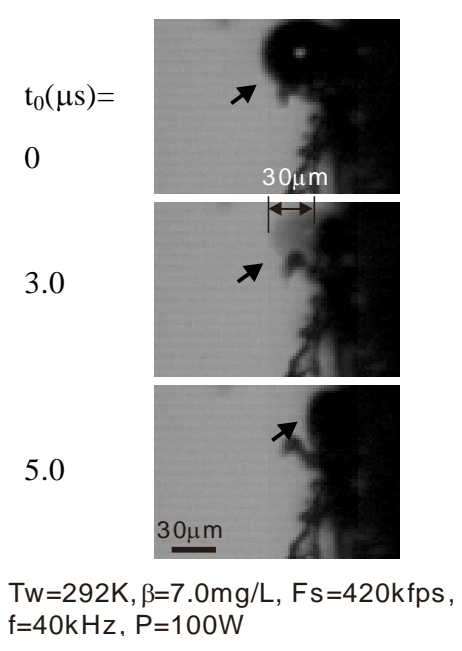

Fig.5 Detailed behavior of bubble collapse 